\title{
Effects of melatonin on cytokine release and healing of colonic anastomoses in an experimental sepsis model
}

\author{
Ömer Faik Ersoy, M.D.,, ${ }^{1}$ Namık Özkan, M.D.,, ${ }^{1}$ Zeki Özsoy, M.D., ${ }^{1}$ Hüseyin Ayhan Kayaoğlu, M.D.,, \\ Erdinç Yenidoğan, M.D., ${ }^{1}$ Alper Çelik, M.D., ${ }^{1}$ Aziz Fikret Özuğurlu, M.D., ${ }^{2}$ \\ Ebru Arabacı Çakır, M.D., ${ }^{3}$ Neşe Lortlar, M.D. ${ }^{4}$
}

${ }^{1}$ Department of General Surgery, Gaziosmanpaşa University Faculty of Medicine, Tokat-Turkey

${ }^{2}$ Department of Biochemistry, Gaziosmanpaşa University Faculty of Medicine, Tokat-Turkey

${ }^{3}$ Department of Pathology, Atatürk Training and Research Hospital, Ankara-Turkey

${ }^{4}$ Department of Histology and Embryology, Gazi University Faculty of Medicine, Ankara-Turkey

\begin{abstract}
BACKGROUND: The present objective was to identify effects of early melatonin application on healing of anastomotic wound and inflammation in an experimental sepsis model.

METHODS: A total of 60 Wistar albino rats were divided into 2 groups. Cecal ligation puncture (CLP) and colonic resection anastomosis were performed on both the control group and the melatonin treatment group. Both groups were divided into 3 subgroups consisting of 10 rats each. One subgroup from each group underwent re-laparotomy at the $16^{\text {th }}$ hour, the next on the $3^{\text {rd }}$ day, and the final subgroup on the $7^{\text {th }}$ day. Presently evaluated were effects of melatonin treatment of early sepsis on interleukin-6 (IL-6), interleukin-I0 (IL-I0), interferon gamma (INF- $\gamma$ ), and C-reactive protein (CRP) levels, as well as burst pressures (BPs), collagen and hydroxyproline (OHP) content of the anastomotic segments, histopathologic healing, immunohistochemical expressions, CD34, and transforming growth factor beta (TGF- $\beta$ ).

RESULTS: IL- 6 and INF- $\gamma$ levels of the treatment group showed a significant decrease at the $16^{\text {th }}$ hour and an increase on the $3^{\text {rd }}$ and $7^{\text {th }}$ postoperative days. IL- 10 levels were significantly higher at the $16^{\text {th }}$ hour and significantly lower on the $3^{\text {rd }}$ and $7^{\text {th }}$ postoperative days in the control group $(p<0.00$ I for each). The treatment group also showed significantly higher capillary permeability, fibroblast proliferation, and collagen deposits $\left(p<0.00 \mathrm{I}\right.$ for each). CD34 expression was significantly increased in the treatment group on the $7^{\text {th }}$ postoperative day $(\mathrm{p}=0.005)$.
\end{abstract}

CONCLUSION: Application of melatonin in early sepsis significantly improved colonic anastomotic healing in a rat model.

Keywords: Anastomosis; colon; melatonin; sepsis.

\section{INTRODUCTION}

Surgery of the colon represents a large share of all surgeries performed in clinical practice. Many factors, some related to the surgeon, affect the success of anastomosis. ${ }^{[1]}$ In spite of improvements in surgical techniques and stapling devices, gastrointestinal anastomoses remain associated with significant morbidity. Sepsis, a well-known etiology of anastomotic breaks, has been the subject of investigation in a number of

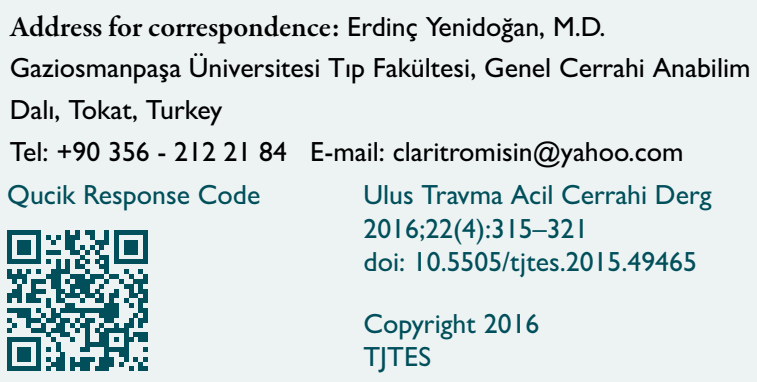

studies. Sepsis is the response of the body to infections generally bacterial in origin. Endotoxemia results in the elaboration of soluble mediators that enhance cellular effector mechanisms, increase in procoagulant and fibroblast activity to localize the invaders, and increase in microvascular blood flow to enhance delivery of immune cells to the source of the sepsis in an attempt to eradicate the pathogens. This systemic response is commonly associated with multiple organ damage, which can lead to death. In cases of septic shock, vasodilatory effects are caused in part to up-regulation of nitric oxide (NO) in the vessel wall. This potent agent plays a central role in diminishing vascular tone, and resists vasoconstrictors. ${ }^{[2]}$ The interaction between pathogens and host leads to activation of macrophages, complement proteins, and immunoglobulins. Excretion of cytokines such as tumor necrosis factor alpha (TNF- $\alpha$ ), interferon gamma (INF- $\gamma$ ), and interleukins (ILs) takes place, depending on the magnitude of the response. Polymorphonuclear leukocyte attraction also occurs. These host defense mechanisms lead to further influx 
of inflammatory fluid into the area of infection, a process that begins within several minutes and may peak within hours. ${ }^{[3]}$

The pineal hormone melatonin plays a fundamental role in the neuro-immuno-endocrine system. Melatonin modulates the immune system with monocyte cytokines, fibroblast proliferation, and growth hormones, which influence angiogenesis. ${ }^{[4]}$ Beneficial effects of melatonin are the product of its effects on antioxidant potential, free-radical scavenger activity, mitogen-activated protein kinase (MAPK) and nuclear factor kappa B (NF-кB) activation, as well as NO expression and nitrite production. NF- $\kappa B$ acts in the modulation of DNA transcription, a critical point in the regulation of cellular processes, such as DNA repair, as well as conditions that require cellular growth, such as sepsis. Melatonin also inhibits the lipopolysaccharide-induced increase in MAPK activation, which promotes tissue inflammation and injury. ${ }^{[5-8]}$ Recent studies have demonstrated the beneficial effects of melatonin on healing of gastric and duodenal ulcers, as well as burn injuries. ${ }^{[9,10]}$ However, the effect of melatonin on colonic healing remains controversial. In the present study, effects of melatonin treatment on cytokine response and colonic anastomotic healing in a sepsis model were evaluated.

\section{MATERIALS AND METHODS}

\section{Experiment Protocol}

Approval of the ethics committee was obtained prior to the start of the study and was based on experiment protocol. All rats received professional human care at the experimental research center. Sixty Wistar albino rats of both sexes, weighing 220-300 g each, were fasted for 12 hours, with free access to water, prior to experiment initiation. Rats were housed (2-3 per wire cage) in an environment with a 12-hour light-dark cycle at a constant temperature of $22-23^{\circ} \mathrm{C}$, and were fed a standard diet. Rats were divided into 2 groups: treatment and control. All rats underwent cecal ligation puncture (CLP) followed by cecal resection, partial colonic resection, and anastomosis. Both groups were then divided into 3 subgroups $\left(16^{\text {th }}\right.$ hour, $3^{\text {rd }}$ day, and $7^{\text {th }}$ day), each consisting of 10 rats.

Sepsis was induced by CLP technique modified by Fujimura et al. ${ }^{\left[{ }^{\prime \prime}\right]}$ Anesthesia of xylazine $(10 \mathrm{mg} / \mathrm{kg})$ and ketamine hydrochloride $(75 \mathrm{mg} / \mathrm{kg}$ ) was administered. Following skin preparation, midline laparotomy of $2-3 \mathrm{~cm}$ was made, and the cecum was ligated just below the ileocecal valve with 3-0 silk in order to maintain intestinal continuity. The cecum was perforated in 2 locations, $1 \mathrm{~cm}$ apart, on the antimesenteric surface, using an 18-gauge needle, and gently compressed until the extrusion of feces was observed. Six hours later, the cecum was resected next to the ileocecal valve. Then, the descending colon was mobilized and a 5-mm segment, approximately $2-3 \mathrm{~cm}$ above the peritoneal reflection, was resected. Next, single-layered, end-to-end anastomosis was performed by the same surgeon, using 5-0 polypropylene (Prolene; Ethicon, Inc., Somerville, NJ, USA) with interrupted inverting sutures. The fascia and skin were closed with 4-0 monofilament running sutures. All animals were resuscitated with subcutaneous injection of $5 \mathrm{~mL}$ saline.

\section{Melatonin Treatment}

Melatonin was dissolved in absolute ethanol, and further dilutions were made in saline. Final concentration of ethanol was $1 \%$. Either melatonin $(10 \mathrm{mg} / \mathrm{kg})$ or $1 \%$ alcohol in saline (I $\mathrm{mL} / \mathrm{kg}$ ) was intraperitoneally administered 30 minutes prior to and 6 hours after surgery, in order to investigate the role of melatonin in the early inflammatory phase of sepsis. ${ }^{[12]}$

\section{Burst Pressure}

All animals were decapitated following induction of anesthesia. Following re-laparotomy performed by an investigator blinded to grouping, a 5-6 cm portion of a colonic segment with anastomosis was resected. Luminal content was cleansed by gentle saline flushing. In order to evaluate burst pressures (BPs) of the anastomotic segments, I end of the colonic segment was tightly sutured with 3-0 silk, and the other was attached to a mercury manometer by a tubing piece with an infusion pump. The colon segment was then placed in a saline-filled container, and air was pumped at a constant pressure of $10 \mathrm{mmHg} / \mathrm{sec}$. As previously described, the pressure at which values suddenly declined or air bubbles were observed was recorded as BP. ${ }^{[13]}$ Potential upper limit of the apparatus was $300 \mathrm{mmHg}$. For this reason, values higher than $300 \mathrm{mmHg}$ were recorded as $300 \mathrm{mmHg}$.

\section{Hydroxyproline Determination in the Intestines}

Tissue samples obtained for hydroxyproline (OHP) determination were washed with serum physiologic and dried at $100^{\circ} \mathrm{C}$ for 72 hours. OHP levels were determined spectrophotometrically by Woessner method. ${ }^{[14]}$ Samples were first weighed and hydrolyzed by dense hydrochloric acid ( $12 \mathrm{~mol} / \mathrm{L}$ hydrogen chloride) at $130^{\circ} \mathrm{C}$ for 3 hours. Each sample was adjusted to I $\mathrm{mL}$ final volume. Samples were centrifuged at $3000 \times \mathrm{g}$ for 15 minutes to obtain a supernatant. A second centrifugation at $2500 \times \mathrm{g}$ was performed for 10 minutes after isopropanol was added to an equal volume of the supernatant. Serial dilutions of commercial pure OHP were used as a standard. OHP concentrations of the samples were calculated using the absorbance-concentration curve of standard OHP solutions. Results were expressed as $\mathrm{mg} / \mathrm{g}$ dry tissue. All samples were assayed in duplicate.

\section{Histopathology}

For light microscopic study, anastomotic segments were fixed in 10\% formaldehyde for 72 hours. The tissues were washed under running tap water and dehydrated with $50 \%, 60 \%, 70 \%$, $80 \%, 90 \%, 96 \%$, and $100 \%$ concentrated ethanol, then placed in a I:I ratio of immersion oil and absolute alcohol for I hour, followed by immersion oil overnight, to achieve transparency. After the application of xylol, specimens were poured into 
paraffin blocks using a I:I xylol and paraffin mixture for I hour and into paraffin for 6 hours in an incubator. Paraffinembedded tissues were sectioned at $5 \mu \mathrm{m}$ and stained with hematoxylin-eosin. Additional sections were stained with Masson's trichrome. During histopathological analysis, healing parameters (fibroblast infiltration, capillary formation) and inflammatory changes (granulocyte and mononuclear cell infiltration) in each specimen were semiquantitatively assessed by assigning a score of $0-3$ for each parameter, as described. ${ }^{[15]}$ Presence or absence of necrosis, exudate, epithelialization, and peritonitis were also recorded. Masson's trichrome stain was assessed for the presence or absence of regular collagen fiber pattern as follows:

No regular collagen fibers=0; Mildly regular collagen fibers $=I$; Moderately regular collagen fibers $=2$; Severely regular collagen fibers $=3$.

\section{Measurement of Cytokines and C-reactive Protein}

Blood samples were collected at the $16^{\text {th }}$ postoperative hour, and on the $3^{\text {rd }}$ and $7^{\text {th }}$ postoperative days. Samples were centrifuged and stored at $-20^{\circ} \mathrm{C}$ until analysis was performed. Interleukin-6 (IL-6), interleukin-I0 (IL-I0), INF- $\gamma$, and C-reactive protein (CRP) levels were measured using a solid-phase sandwich enzyme-linked immunosorbent assay (ELISA) by automatic micro ELISA Tritus analyzer (Grifols, S.A., Barcelona, Spain). Rat IL-6, IL-I0, INF- $\gamma$, and CRP ELISA kits (MyBioSource, Inc., San Diego, CA, USA) were used.

\section{Immunohistochemical Method}

Avidin-biotin-peroxidase complex techniques were used for immunohistochemical staining. ${ }^{[16]}$ The slides were incubated overnight at $37^{\circ} \mathrm{C}$, then for I hour at $60^{\circ} \mathrm{C}$. Next, they were de-waxed in 2 cycles of xylene ( 15 minutes each) and rehydrated with descendent ethyl alcohol gradient for 10 minutes each, followed by 2 -minute changes of distilled water. The sections were boiled in citrate buffer in a microwave oven for 5 minutes at $650 \mathrm{~W}$ and for $3 \times 5$ minutes at $550 \mathrm{~W}$. After 20 minutes at room temperature, the tissues were rolled with a PAP pen (Beckman Coulter Inc., Brea, CA, USA). The tissues were washed with distilled water, then with phosphatebuffered saline (PBS), and endogenous peroxidase activity in the tissues was blocked in 3\% hydrogen peroxide for 20 minutes. PBS-diluted Ultra $V$ block (Thermo Fisher Scientific, Inc., Waltham, MA, USA) was applied for 5 minutes. Following I-hour application of primary antibodies - transforming growth factor beta 3 (TGF- $\beta 3$; Vet Pharma Friesoythe $\mathrm{GmbH}$, Friesoythe, Germany) and CD34 (Lab Vision/Neomarkers, Inc., Freemont, CA, USA) - diluted with antibody diluents (Thermo Fisher Scientific, Inc., Waltham, MA, USA), the samples were washed with PBS. Secondary antibody- biotinylated anti-polyvalent - was applied for 20 minutes. After the slides were washed with PBS, they were exposed to streptavidin peroxidase for 20 minutes. The specimens were rewashed with PBS and placed in 3-amino-9-ethylcarbazole (AEC) chromogen for 10 minutes. Finally, counter-staining with Mayer's hematoxylin was performed for 2 minutes. All slides were evaluated using a Leica DMI 4000B light microscope (Leica Microsystems $\mathrm{GmbH}$, Wetzlar, Germany) and photographed with Leica QWin Pro (version 3.4.0; Calidris \& SoftHard Technology Ltd., Marianka, Slovakia).

Two researchers blinded to grouping independently evaluated staining intensity. The following staining intensity designation was used: 0 for no involvement; I (+) for slight involvement; 2 $(++)$ for mild involvement; and $3(+++)$ for strong involvement of the primary antibody. The entire slide of each specimen was examined, and final scoring was based upon the predominant areas with the highest grade of staining intensity. Labelling intensity was graded semi-quantitatively, and HSCORE was calculated using the following equation: HSCORE $=\mathrm{Pi}(\mathrm{i}+$ $I)$, where $i$ is the intensity of labelling with a value of $I, 2$, or 3 and $\mathrm{Pi}$ is the percentage of labelled epithelial and stromal cells for each intensity, varying from $0-100 \% .{ }^{[17]}$

\section{Statistical Analysis}

Statistical evaluation of numeric variables was performed with I-way analysis of variance, followed by post-hoc Tukey. Nonnumeric variables were evaluated with $\chi^{2}$ test. A p value of less than 0.05 was considered statistically significant.

\section{RESULTS}

Two mortalities were observed in the control group: at the $16^{\text {th }}$ postoperative hour and on the $3^{\text {rd }}$ postoperative day. Statistical analysis was performed excluding these mortalities. BPs and OHP levels are shown in Table I. BP levels were slightly higher but insignificant in the treatment group at the $16^{\text {th }}$ hour and on the $3^{\text {rd }}$ day $(p=1.0$ and $p=0.99$, respectively). BP elevation was statistically significant in the treatment group on the $7^{\text {th }}$ day (|46. I $\pm 50.74 \mathrm{mmHg}$ vs $193.0 \pm 26.58 \mathrm{mmHg}, \mathrm{P}<0.00$ I). OHP levels at the anastomotic site showed significant improvement in the treatment group $(77.73 \pm 24.87 \mu \mathrm{g} / \mathrm{mg}$ vs $132.26 \pm 48.48$ $\mu \mathrm{g} / \mathrm{mg}$ at the $16^{\text {th }}$ hour; $129.5 \pm 13.6 \mu \mathrm{g} / \mathrm{mg}$ vs $197.07 \pm 56.52 \mu \mathrm{g} /$ $\mathrm{mg}$ on the $3^{\text {rd }}$ day; and $198.31 \pm 33.59 \mu \mathrm{g} / \mathrm{mg}$ vs $224.67 \pm 61.16$ $\mu \mathrm{g} / \mathrm{mg}$ on the $7^{\text {th }}$ day in the control and treatment groups, respectively; $p=0.008, p=0.016$, and $p=0.0$ I, respectively).

Histologically, fibroblastic proliferation and capillary permeability as indicators of wound healing were improved in the treatment group, with statistically significant difference ( $p<0.00$ I, Figs. I, 2). Collagen deposits showed significantly better deposition, by Masson's trichrome staining, in the treatment group ( $p<0.00$ I, Fig. 3). Demonstrative histological sections are shown in Figure 4a-d.

Cytokine levels differed significantly over time. In the treatment group, inflammatory cytokines (IL-6 and INF- $\gamma$ ) were significantly lower at the $16^{\text {th }}$ hour and significantly higher during the $3^{\text {rd }}$ and $7^{\text {th }}$ postoperative days $(p<0.001$ for each). Levels of regulatory cytokine (IL-I0) were significantly higher at the 
Table I. Burst pressures and hydroxyproline levels in all groups

\begin{tabular}{|c|c|c|c|c|}
\hline & \multirow[t]{2}{*}{ Sacrification time } & \multirow{2}{*}{$\begin{array}{c}\text { Control } \\
\text { Mean } \pm S D\end{array}$} & \multirow{2}{*}{$\frac{\text { Treatment (Melatonin) }}{\text { Mean } \pm \text { SD }}$} & \multirow[t]{2}{*}{$\mathbf{p}$} \\
\hline & & & & \\
\hline \multirow[t]{3}{*}{ Burst pressure $(\mathrm{mmHg})$} & $16^{\text {th }}$ hour & $7.40 \pm 5.25$ & $8.33 \pm 5.46$ & $=1.0$ \\
\hline & Third POD & $40.0 \pm 15.09$ & $45.89 \pm 10.52$ & $=0.99$ \\
\hline & Seventh POD & $|46| \pm 50.74$. & $193.0 \pm 26.58$ & $<0.001^{*}$ \\
\hline \multirow[t]{3}{*}{ Hydroxyproline-Proline Level ( $\mu \mathrm{g} / \mathrm{mg})$} & $16^{\text {th }}$ hour & $77.73 \pm 24.87$ & $132.26 \pm 48.48$ & $=0.008^{*}$ \\
\hline & Third POD & $129.5 \pm 13.6$ & $197.07 \pm 56.52$ & $=0.016^{*}$ \\
\hline & Seventh POD & $198.31 \pm 33.59$ & $224.67 \pm 61.16$ & $=0.01^{*}$ \\
\hline
\end{tabular}

*Melatonin-treated rats had significantly elevated BP on the seventh POD and higher OHP levels in all periods examined. SD: Standard deviation.

$16^{\text {th }}$ hour and significantly lower on the $3^{\text {rd }}$ and $7^{\text {th }}$ postoperative days $(p<0.001$ for each). CRP levels were also significantly lower in the treatment group at the 16th hour. CRP levels of the treatment group tended to be lower than those of the

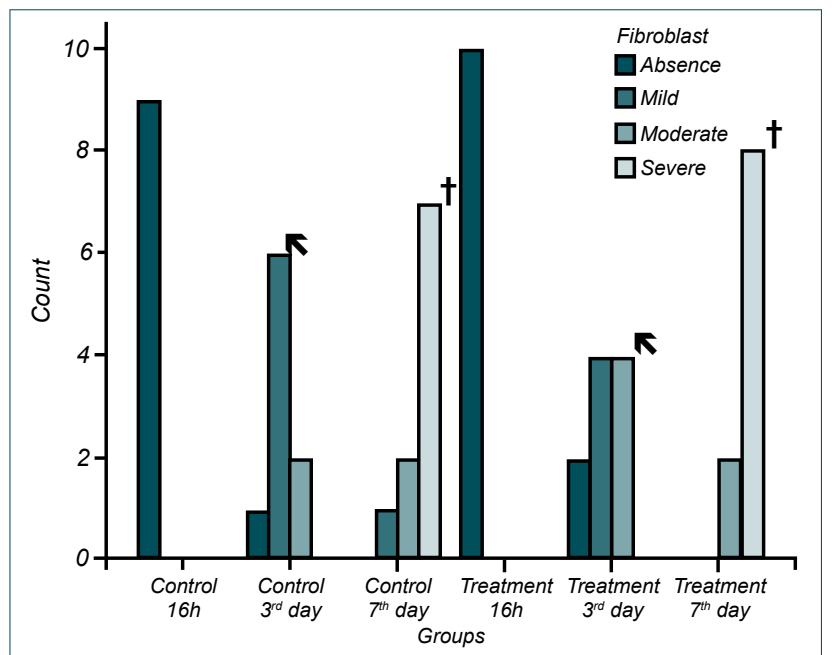

Figure 1. Fibroblastic proliferation was significantly improved in the treatment group at the $3^{\text {rd }}$ and $7^{\text {th }}$ postoperative days $(p<0.001)$.

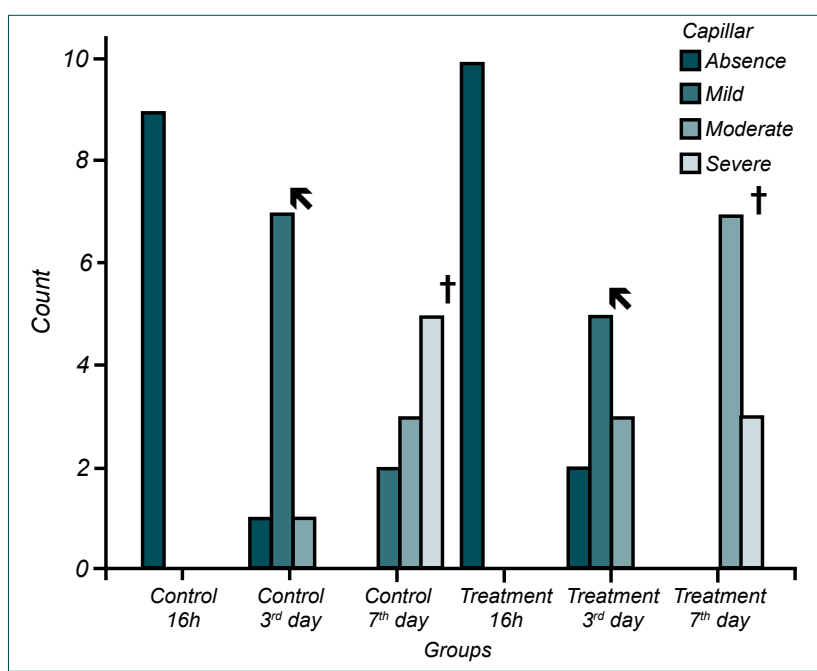

Figure 2. Capillary formation, an indicator of wound healing, increased over time in the treatment group, with significant difference $(p<0.001)$ control group on the $3^{\text {rd }}$ and $7^{\text {th }}$ postoperative days, but the difference was not statistically significant $(p=0.38$ and $p=0.99$, respectively). Cytokine and CRP levels are shown in Table 2.

Immunohistochemical evaluation of CD34 revealed similar results between the groups at the $16^{\text {th }}$ hour $(p=1.0)$. On the $3^{\text {rd }}$ postoperative day, the treatment group showed a slight increase in CD34 levels, but the difference was not statistically significant $(p=0.057)$. On the $7^{\text {th }}$ postoperative day, CD34 expression of the treatment group was significantly higher $(p=0.005)$ (Fig. 5a, b).

Expression of TGF- $\beta$ at the anastomotic site showed significantly higher levels in the treatment group at the $16^{\text {th }}$ postoperative hour, and on the $3^{\text {rd }}$ and $7^{\text {th }}$ postoperative days $(p=0.019, p=0.001$, and $p=0.008$, respectively). TGF- $\beta$ levels are listed in Table 3.

\section{DISCUSSION}

Numerous attempts have been made to lower incidence of

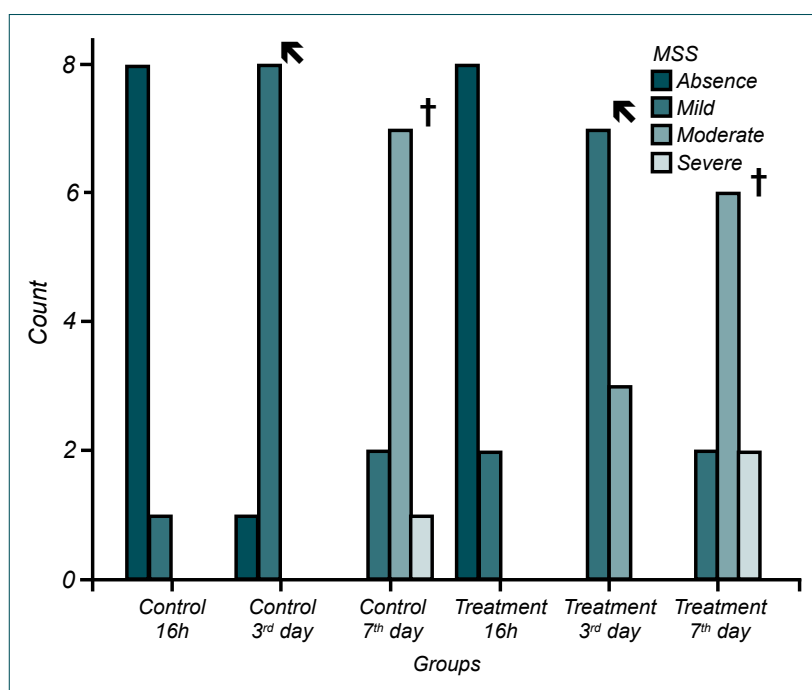

Figure 3. Collagen deposition was evaluated by Masson's trichrome staining, and showed significantly better results in the treatment group, particularly at the $3^{\text {rd }}$ and $7^{\text {th }}$ postoperative days $(p<0.001)$. 
Table 2. CRP and cytokine levels exhibited significant differences between treated and control rats

\begin{tabular}{|c|c|c|c|}
\hline \multirow[t]{2}{*}{ Sacrification time } & \multirow{2}{*}{$\begin{array}{l}\text { Control } \\
\text { Mean士SD }\end{array}$} & \multirow{2}{*}{$\begin{array}{c}\begin{array}{c}\text { Treatment } \\
\text { (Melatonin) }\end{array} \\
\text { Mean士SD }\end{array}$} & \multirow[t]{2}{*}{$\mathbf{p}$} \\
\hline & & & \\
\hline \multicolumn{4}{|l|}{ IL-6 (pg/ml) } \\
\hline $16^{\text {th }}$ hour & $3005.19 \pm 93.95$ & $1054.84 \pm 135.97$ & $<0.001$ \\
\hline Third POD & $110.52 \pm 22.37$ & $270.62 \pm 67.14$ & \\
\hline Seventh POD & $92.48 \pm 18.36$ & $151.13 \pm 35.52$ & \\
\hline \multicolumn{4}{|l|}{ IL-I0 (pg/ml) } \\
\hline $16^{\text {th }}$ hour & $161.59 \pm 28.11$ & $803.64 \pm 405.09$ & $<0.001$ \\
\hline Third POD & $35.42 \pm 28.31$ & $24.29 \pm 10.83$ & \\
\hline Seventh POD & $29.60 \pm 12.06$ & $23.57 \pm 6.93$ & \\
\hline \multicolumn{4}{|l|}{ Interferon $\gamma(\mathrm{pg} / \mathrm{ml})$} \\
\hline $16^{\text {th }}$ hour & $46.01 \pm 11.18$ & $28.15 \pm 7.86$ & $<0.001$ \\
\hline Third POD & $20.23 \pm 3.45$ & $22.67 \pm 6.51$ & \\
\hline Seventh POD & $27.25 \pm 5.08$ & $42.41 \pm 15.03$ & \\
\hline \multicolumn{4}{|l|}{ CRP (ng/ml) } \\
\hline $16^{\text {th }}$ hour & $48.91 \pm 5.85$ & $35.49 \pm 4.65$ & $<0.05$ \\
\hline Third POD & $47.04 \pm 12.35$ & $39.92 \pm 12.42$ & 0.38 \\
\hline Seventh POD & $42.04 \pm 9.34$ & $39.57 \pm 6.35$ & 0.99 \\
\hline
\end{tabular}

Proinflammatory cytokines were significantly lower in treatment groups at $16^{\text {th }}$ hour and reversed on the third and seventh PODs. CRP levels were significantly lower in treatment group at $16^{\text {th }}$ hour and although insignificant, remained at lower levels throughout the study. SD: Standard deviation.

anastomotic leakage and related complications in cases of colorectal surgery. Effects of melatonin on the integrity of colonic anastomoses in septic conditions were presently investigated with a rat model. The idea of treating septic animals

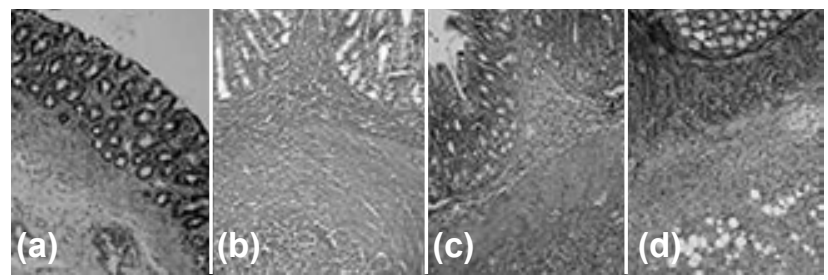

Figure 4. (a) Mild granulocyte, fibroblast infiltration, and capillary formation, (b) moderate granulocyte and fibroblast infiltration, (c) severe granulocyte infiltration, and (d) moderate fibroblast proliferation in the subserosal layer. ([a-c]: Hematoxylin-eosin, x20 magnification; [d] Masson's trichrome stain, $x 20$ magnification).

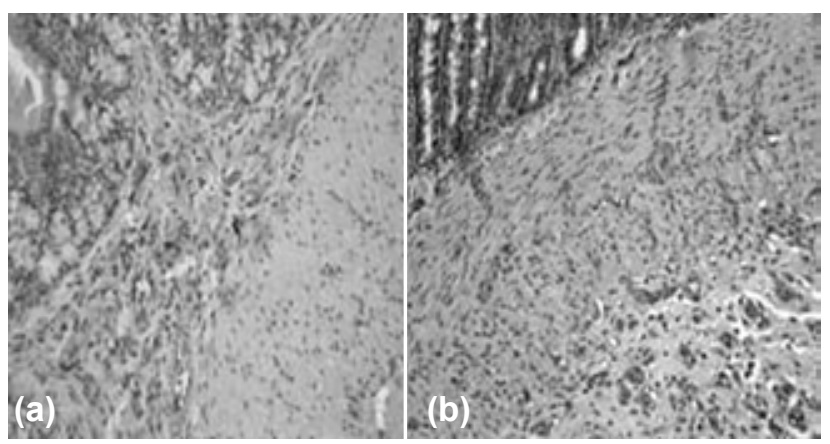

Figure 5. (a) Immunohistochemical demonstration of mild, and (b) moderate CD34 expression (x100 magnification).
Table 3. Transforming growth factor beta expression at the anastomotic site, distributed according to histological examination, showed markedly higher levels in the treatment group at all intervals

\begin{tabular}{|c|c|c|c|c|c|}
\hline \multirow[t]{2}{*}{ Groups } & \multicolumn{2}{|c|}{ Control } & \multicolumn{2}{|c|}{$\begin{array}{l}\text { Treatment } \\
\text { (Melatonin) }\end{array}$} & \multirow[t]{2}{*}{$\mathbf{p}$} \\
\hline & $\mathbf{n}$ & $\%$ & $\mathbf{n}$ & $\%$ & \\
\hline \multicolumn{6}{|l|}{ TGF- $\beta$} \\
\hline \multicolumn{6}{|l|}{$16^{\text {th }}$ hour } \\
\hline Absence & 5 & 55.6 & 0 & 0 & 0.019 \\
\hline Mild & 4 & 44.4 & 9 & 90.0 & \\
\hline Moderate & 0 & 0 & I & 10.0 & \\
\hline Severe & 0 & 0 & 0 & 0 & \\
\hline \multicolumn{6}{|l|}{ Third POD } \\
\hline Absence & 0 & 0 & 0 & 0 & 0.001 \\
\hline Mild & 9 & 90.0 & 2 & 20.0 & \\
\hline Moderate & 0 & 0 & 8 & 80.0 & \\
\hline Severe & 0 & 0 & 0 & 0 & \\
\hline \multicolumn{6}{|l|}{ Seventh POD } \\
\hline Absence & 0 & 0 & 0 & 0 & 0.008 \\
\hline Mild & 6 & 60.0 & 2 & 0 & \\
\hline Moderate & 2 & 20.0 & 8 & 20.0 & \\
\hline Severe & 2 & 20.0 & 0 & 80.0 & \\
\hline
\end{tabular}

with melatonin originated in the hypothesis that this product had potential antioxidant effects and was a potent free radical scavenger. In another vital effect, melatonin stimulates activity of the endogenous antioxidant enzymes glutathione and myeloperoxidase. ${ }^{[18-20]}$ Melatonin also has immune-regulatory and anti-edematogenic effects. The immune-regulatory effects of melatonin are associated with a reduction in MAPK and NF-KB activation, down-regulation of a variety of proinflammatory cytokines, expression of inducible NO synthase, and production of nitrite. ${ }^{[20-22]}$

The present results demonstrate that melatonin treatment administered during the early phase of sepsis leads to early decline in inflammatory cytokines (IL-6 and INF- $\gamma$ ) and increase in levels of regulatory cytokine (IL-I0). However, this effect was reversed on the $3^{\text {rd }}$ and $7^{\text {th }}$ postoperative days. IL-10 is able to induce modified cytokine secretion pattern with suppression of TNF- $\alpha$, IL-I, IL-6, and IL-8, and can inhibit antigen-presenting capacity. IL-10 also has both direct and cytokine-related indirect effects on monocytes and macrophages. Therefore, IL-10 appears to be an important candidate for the induction of immunoparalysis, which frequently follows a hyperinflammatory phase. Interestingly, IL10 inhibits its own production and TNF- $\alpha$ blockade leads to the inhibition of endotoxin-induced IL- 10 formation in human monocytes. The purpose of these consecutive inflammation and anti-inflammation phases is to protect the organism 
against the consequences of whole-body inflammation. Interestingly, 2 peaks of IL- 10 production can be detected in vivo. The "late" IL- 10 peak can be detected in plasma 8 hours after endotoxin exposure, and is regulated by TNF- $\alpha$. The "early" IL- I 0 peak can be detected I-2 hours after exposure and explains the monocyte deactivation that is observed following trauma. Normally, monocytes recover spontaneously within 24-72 hours. Persistence of deactivation is associated with high rate of infection. ${ }^{[23-25]}$ In the present study, IL- I0 levels were initially higher in treated rats and decreased on the $3^{\text {rd }}$ and $7^{\text {th }}$ postoperative days. We believe that immunoregulatory effects of melatonin assisted in the normalization of IL- 10 levels, preserving monocyte and macrophage functions.

Rate of CRP synthesis directly reflects the intensity of the inflammatory process. Anastomotic leak, wound infection, tissue ischemia, and necrosis activate CRP production. ${ }^{[26,27]}$ In septic patients, decrease in CRP levels indicates a higher survival rate or resolution of sepsis. ${ }^{[28,29]}$ CRP levels were significantly lower in the treatment group at the $16^{\text {th }}$ hour, and remained at levels lower than those of the control group on the $3^{\text {rd }}$ and $7^{\text {th }}$ postoperative days. We believe that the decrease in CRP levels in treated rats confirms the anti-inflammatory role of melatonin during sepsis.

Beneficial effects of melatonin on wound healing have been documented. Soybir et al. investigated the role of melatonin in an experimental wound healing model and detected a higher number of macrophages, fibroblasts, neovascularizations, and higher collagen density in treated animals. The authors determined that exogenous melatonin has positive effects on the angiogenic phase of wound healing. ${ }^{[4]}$ As OHP is the main determinant of collagen content within tissue, a correlation exists. ${ }^{[30]}$ In the present study, higher levels of OHP were observed in the treatment group at all times, and significantly higher collagen deposits were also observed. BPs measured on the $7^{\text {th }}$ postoperative day were significantly higher in treated rats. Although insignificant, BP levels were also slightly higher in the treatment group at the $16^{\text {th }}$ hour and $3^{\text {rd }}$ postoperative day. Overall, the present results have demonstrated a correlation between OHP levels, collagen deposits, and BP. According to the data, it can be concluded that exogenous melatonin has regulatory and supportive effects on wound healing and collagenization.

Pugazhenthi et al. were the first to demonstrate accelerated wound healing with melatonin in rats. The results also confirmed modulated key biological processes, such as collagen synthesis, scar formation, inflammation, and angiogenesis. ${ }^{[21]}$ However, no consensus regarding the effects of melatonin on wound healing has been reached since. Bulbuller et al. reported that exogenous melatonin decreased collagen synthesis and epithelium proliferation, and had negative effects on wound healing in both normal and pinealectomized rats. ${ }^{[31]}$ Similarly, Ozdogan et al. found no beneficial effect of exogenous melatonin on colonic anastomosis. ${ }^{[30]}$ On the other hand, Ozen et al. reported that melatonin had a dose-independent positive effect on wound healing of colonic anastomosis in the presence of peritonitis. The authors found significantly higher burst pressure and glutathione levels in rats treated with a high dose of melatonin. In addition, malondialdehyde, blood TNF- $\alpha$, and IL-6 levels were significantly low in the same group. ${ }^{[32]}$

Mechanisms associated with melatonin that may accelerate wound healing were presently investigated. One mechanism was TGF- $\beta$-associated collagen synthesis. Melatonin has been shown to induce production of TGF- $\beta,{ }^{[4]}$ which plays a significant role in promoting collagen synthesis and healing the colon. ${ }^{[33]}$ In the present study, TGF- $\beta$ levels were higher in treated rats, corresponding to improved colonic healing. The present findings regarding the effect of melatonin on angiogenesis support those of previous studies. Melatonin increases the number of vessels in wounded tissue. ${ }^{[4]}$ Status of angiogenesis was investigated using CD34 expression. CD34 is a transmembrane glycoprotein that is primarily present in the endothelial cells. Detection of this molecule facilitates identification of blood vessels and endothelial cells in tissues adjacent to the wound site. ${ }^{[34]}$ A steady increase in CD34 expression was presently found in the treatment group. We believe that these high CD34 levels confirm increased angiogenesis and better anastomotic healing in melatonin-treated rats.

In conclusion, the present study demonstrated the protective effects of melatonin on anastomotic healing during sepsis. Increased TGF- $\beta$ levels and CD34 expression were detected in the group treated with melatonin, positively affecting collagen synthesis and angiogenesis. Moreover, in the early period, IL10 levels were significantly higher and CRP levels were significantly lower in treated rats, confirming the anti-inflammatory property of melatonin in the treatment of sepsis. Further studies in which a variety of doses are administered by various application routes are warranted.

\section{Conflict of interest: None declared.}

\section{REFERENCES}

1. Nursal TZ, Anarat R, Bircan S, Yildirim S, Tarim A, Haberal M. The effect of tissue adhesive, octyl-cyanoacrylate, on the healing of experimental high-risk and normal colonic anastomoses. Am J Surg 2004;187:28-32.

2. Peitzman AB, Harbrecht BG, Billiar TR. Shock. In: Brunicardi FC, Andersen DK, Biliar TR, et al. editors. Schwartz's, Principles of Surgery. 8th ed. New York: McGraw Hill Company; 2005. p. 85-107.

3. Dunn DL, Beilman GJ. Surgical infections. In: Brunicardi FC, Andersen DK, Biliar TR, et al. editors. Schwartz's, Principles of Surgery. 8th ed. New York: McGraw Hill Company; 2005. p. 109-27.

4. Soybir G, Topuzlu C, Odabaş O, Dolay K, Bilir A, Köksoy F. The effects of melatonin on angiogenesis and wound healing. Surg Today 2003;33:896-901.

5. Baldwin AS Jr, Sharp PA. Two transcription factors, NF-kappa B and H2TF1, interact with a single regulatory sequence in the class I major histocompatibility complex promoter. Proc Natl Acad Sci U S A 1988;85:723-7.

6. Schreck R, Baeuerle PA. NF-kappa B as inducible transcriptional activator of the granulocyte-macrophage colony-stimulating factor gene. Mol Cell Biol 1990;10:1281-6.

7. Böhnlein E, Lowenthal JW, Siekevitz M, Ballard DW, Franza BR, Greene WC. The same inducible nuclear proteins regulates mitogen activation of both the interleukin-2 receptor-alpha gene and type 1 HIV. Cell 
1988;53:827-36.

8. De Filippis D, Iuvone T, Esposito G, Steardo L, Arnold GH, Paul AP, et al. Melatonin reverses lipopolysaccharide-induced gastro-intestinal motility disturbances through the inhibition of oxidative stress. J Pineal Res 2008;44:45-51.

9. Celinski K, Konturek PC, Konturek SJ, Slomka M, Cichoz-Lach H, Brzozowski T, et al. Effects of melatonin and tryptophan on healing of gastric and duodenal ulcers with Helicobacter pylori infection in humans. J Physiol Pharmacol 2011;62:521-6.

10. Sahib AS, Al-Jawad FH, Alkaisy AA. Effect of antioxidants on the incidence of wound infection in burn patients. Ann Burns Fire Disasters 2010;23:199-205.

11. Fujimura N, Sumita S, Narimatsu E, Nakayama Y, Shitinohe Y, Namiki A. Effects of isoproterenol on diaphragmatic contractility in septic peritonitis. Am J Respir Crit Care Med 2000;161(2 Pt 1):440-6.

12. Paskaloğlu K, Sener G, Kapucu C, Ayanoğlu-Dülger G. Melatonin treatment protects against sepsis-induced functional and biochemical changes in rat ileum and urinary bladder. Life Sci 2004;74:1093-104.

13. Yamaner $S$, Buğra D, Müslümanoğlu M, Bulut T, Cubukçu $O$, Ademoğlu E. Effects of octreotide on healing of intestinal anastomosis following small bowel obstruction in rats. Dis Colon Rectum 1995;38:308-12.

14. Woessner JF Jr. The determination of hydroxyproline in tissue and protein samples containing small proportions of this imino acid. Arch Biochem Biophys 1961;93:440-7.

15. Nursal TZ, Bal N, Anarat R, Colakoglu T, Noyan T, Moray G, et al. Effects of a static magnetic field on wound healing: results in experimental rat colon anastomoses. Am J Surg 2006;192:76-81.

16. Hsu SM, Raine L, Fanger H. Use of avidin-biotin-peroxidase complex $(\mathrm{ABC})$ in immunoperoxidase techniques: a comparison between $\mathrm{ABC}$ and unlabeled antibody (PAP) procedures. J Histochem Cytochem 1981;29:577-80.

17. McCarty KS Jr, Miller LS, Cox EB, Konrath J, McCarty KS Sr. Estrogen receptor analyses. Correlation of biochemical and immunohistochemical methods using monoclonal antireceptor antibodies. Arch Pathol Lab Med 1985;109:716-21.

18. Reiter RJ, Tan DX, Osuna C, Gitto E. Actions of melatonin in the reduction of oxidative stress. A review. J Biomed Sci 2000;7:444-58.

19. Sener G, Toklu H, Kapucu C, Ercan F, Erkanli G, Kaçmaz A, et al. Melatonin protects against oxidative organ injury in a rat model of sepsis. Surg Today 2005;35:52-9.

20. Wu CC, Chiao CW, Hsiao G, Chen A, Yen MH. Melatonin prevents en- dotoxin-induced circulatory failure in rats. J Pineal Res 2001;30:147-56.

21. Pugazhenthi K, Kapoor M, Clarkson AN, Hall I, Appleton I. Melatonin accelerates the process of wound repair in full-thickness incisional wounds. J Pineal Res 2008;44(4):387-96.

22. Li JH, Yu JP, Yu HG, Xu XM, Yu LL, Liu J, et al. Melatonin reduces inflammatory injury through inhibiting NF-kappaB activation in rats with colitis. Mediators Inflamm. 2005;2005:185-93.

23. Platzer C, Meisel C, Vogt K, Platzer M, Volk HD. Up-regulation of monocytic IL-10 by tumor necrosis factor-alpha and cAMP elevating drugs. Int Immunol 1995;7:517-23.

24. Barsig J, Küsters S, Vogt K, Volk HD, Tiegs G, Wendel A. Lipopolysaccharide-induced interleukin-10 in mice: role of endogenous tumor necrosis factor-alpha. Eur J Immunol 1995;25:2888-93.

25. Volk HD, Reinke P, Krausch D, Zuckermann H, Asadullah K, Müller $\mathrm{JM}$, et al. Monocyte deactivation--rationale for a new therapeutic strategy in sepsis. Intensive Care Med 1996;22 Suppl 4:474-81.

26. Pepys MB, Hirschfield GM. C-reactive protein: a critical update. J Clin Invest 2003;111:1805-12.

27. Millan M, García-Granero E, Flor B, García-Botello S, Lledo S. Early prediction of anastomotic leak in colorectal cancer surgery by intramucosal pH. Dis Colon Rectum 2006;49:595-601.

28. Yentis SM, Soni N, Sheldon J. C-reactive protein as an indicator of resolution of sepsis in the intensive care unit. Intensive Care Med 1995;21:602-5.

29. Claeys R, Vinken S, Spapen H, ver Elst K, Decochez K, Huyghens L, et al. Plasma procalcitonin and $\mathrm{C}$-reactive protein in acute septic shock: clinical and biological correlates. Crit Care Med 2002;30:757-62.

30. Ozdogan M, Oruk I, Renda N, Kaynaroglu V, Baykal A. The effect of exogenous melatonin on experimental colonic anastomosis. Acta Chir Belg 2005;105:302-5.

31. Bulbuller N, Dogru O, Yekeler H, Cetinkaya Z, Ilhan N, Kirkil C. Effect of melatonin on wound healing in normal and pinealectomized rats. J Surg Res 2005;123:3-7.

32. Ozen IO, Ekingen G, Taşlipinar MY, Bukan N, Demiroğullari B, Karabulut $\mathrm{R}$, et al. Effect of melatonin on healing of colonic anastomosis in a rat model of peritonitis. Eur Surg Res 2007;39:122-7.

33. Buckmire MA, Parquet G, Greenway S, Rolandelli RH. Temporal expression of TGF-beta1, EGF, and PDGF-BB in a model of colonic wound healing. J Surg Res 1998;80:52-7.

34. Lu C, Marcucio R, Miclau T. Assessing angiogenesis during fracture healing. Iowa Orthop J 2006;26:17-26.

\title{
DENEYSEL ÇALIŞMA - ÖZET
}

\section{Deneysel sepsis modelinde melatoninin sitokin salınımı ve kolonik anastomoz iyileşmesi üzerine etkileri}

\section{Dr. Ömer Faik Ersoy, ${ }^{1}$ Dr. Namık Özkan, ${ }^{1}$ Dr. Zeki Özsoy, ${ }^{1}$ Dr. Hüseyin Ayhan Kayaoğlu, ${ }^{1}$ Dr. Erdinç Yenidoğan, ${ }^{1}$ Dr. Alper Çelik, ${ }^{1}$ Dr. Aziz Fikret Özuğurlu, ${ }^{2}$ Dr. Ebru Arabacı Çakır, ${ }^{3}$ Dr. Neşe Lortlar ${ }^{4}$}

\author{
${ }^{1}$ Gaziosmanpaşa Üniversitesi Tıp Fakültesi, Genel Cerrahi Anabilim Dalı, Tokat \\ ${ }^{2}$ Gaziosmanpaşa Üniversitesi Tıp Fakültesi, Biyokimya Anabilim Dalı, Tokat \\ ${ }^{3}$ Atatürk Eğitim ve Araştırma Hastanesi, Patoloji Kliniği, Ankara \\ 4Gazi Üniversitesi Tıp Fakültesi, Histoloji ve Embriyoloji Anabilim Dalı, Ankara
}

AMAÇ: Deneysel sepsis modelinde erken dönem melatonin uygulamasının anastomoz yara iyileşmesi ve enflamasyon üzerine olan etkilerini göstermeyi amaçladık.

GEREÇ VE YÖNTEM: Altmış Wistar-Albino sıçan iki gruba ayrıldı. Melatonin ve kontrol gruplarına çekal ligasyon ve puncture ile kolonik rezeksiyon ve anastomoz yapıldı. Her iki gruptan 10'ar sıçana 16. saat, üçüncü ve yedinci günlerde relaparotomi yapıldı. Erken dönem sepsiste melatonin tedavisinin etkilerini incelemek amacıyla interlökin-6, interlökin- I0, interferon-gama, C-reaktif protein düzeyleri, patlama basınçları, anastomotik segmentlerdeki kollajen hidroksiprolin içeriği, histopatolojik iyileşme düzeyleri ve CD34 ve "transforming growth factor beta" immünhistokimyasal düzeyleri değerlendirildi.

BULGULAR: Tedavi grubunda interlökin-6 ve interferon-gama düzeylerinin ameliyat sonrası I6. saatte anlamlı olarak azaldığı, üçüncü ve yedinci günlerde ise artmış olduğu bulundu. Interlökin- 10 düzeyleri ise kontrol grubunda ameliyat sonrası I6. saatte anlamlı olarak artmışken, üçüncü ve yedinci günlerde düşük bulundu $(p<0.001)$. Aynı zamanda tedavi grubunda kapiller permeabilite, fibroblast proliferasyonu ve kollajen depositleri anlamlı olarak yüksek bulundu ( $p<0.00$ I). CD34 ekspresyonu tedavi grubunda ameliyat sonrası yedinci günde anlamlı olarak yüksek bulundu ( $p=0.005)$. TARTIŞMA: Sıçan modelinde erken sepsis döneminde melatonin uygulamasının kolonik anastomoz iyileşmesini anlamlı olarak artırdı̋̆ını düşünüyoruz. Anahtar sözcükler: Anastomosis; colon; melatonin; sepsis. 